\title{
認知症高齢者がおだやかに， その人らしく生活するための尺度開発
}

\author{
辻村弘美 ${ }^{1}$
}

は じめに

認知症高齢者は年及増加の一途をたどり, 65 歳以上の 高齢者のうち, 認知症の人は推計 $15 \%$ で, 2012 年時点で 約 462 万人に上る. また, 認知症になる可能性がある軽 度認知障害 $(\mathrm{MCI})$ の高齢者も約 400 万人と推計されて 抢り, 65 歳以上の 4 人に 1 人が認知症とその予備軍とな

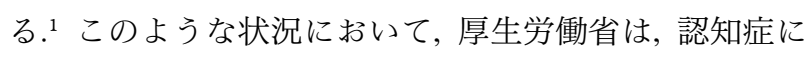
なっても地域で暮らし続けられることを目指したオレン ジプランと呼ばれる「認知症施策推進 5 か年計画」を発 表した.このように, 認知症高齢者のケアの重要性が叫 ばれる中, 筆者らは, 認知症高齢者が扔だやかにその人 らしく生活できるための尺度開発の研究に取り組んでお り，その概要や流れなどについて今回ご紹介する，また， 本研究の一部は貴学会の学術雑誌湟載 2 されているの で, 興味のある方はご一読いただきたい.

\section{認知症高齢者のおだやかスケールについて}

認知症ケアの臨床現場においては, 認知症になっても おだやかに過ごす人やその状態に遭遇する、筆者らは, 認知症高齢者のおだやかさをとら元，おだやかさの背景 を探る研究などを行っている. 認知症高齢者のネガティ ブな部分に焦点をあてるのではなく, パーソン・セン タード・ケアと言わ机るように, 認知症になっても, その 人らしく, おだやかに生活されているといったポジティ ブな状況を評価する尺度である.また，本スケールは，介 護や看護を提供する側から見た, 客観的な状況を観察す る尺度であり, 原案は, 介護者である介護士からの「認知 症高齢者の扔だやか像」についての自由記載をもとに作 成された，その後, 信頼性・妥当性の検証を積み重ね, 現 在は, 〈周囲との交流〉,〈自分らしさの発揮〉,〈満足した暮 らしぶり〉の 3 領域 20 項目からなる尺度である.

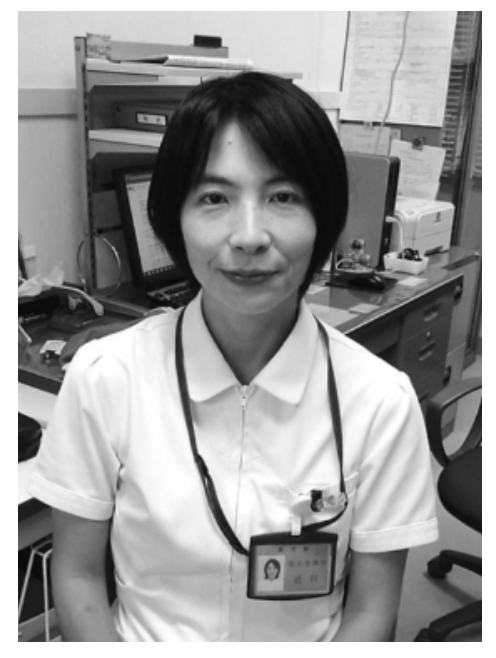

\section{おだやかに生活する認知症高齢者の特徵}

小泉ら ${ }^{3}$ の研究では, 本スケールで得点が高かった認 知症高齢者を対象にして, 対象者が, どのような生活背 景や性格傾向があるか調查した. 対象者の臨床認知症基 準 (CDR) は, 軽度から中等度であり, Big Five 性格尺度 を用いた認知症発病前後での性格評価では, 発病前の性 格が外向的であり, 発病後もその傾向が保持されていた。 また, おだやかに生活できている背景として, 自分らし さが発揮できて抢り，好きなことに打ち込めていたこと が挙げられた.この研究では, 39 名をスクリーニングし 最終的には 9 名を対象者としたが, 今後は, 症例数を増 やすことで信頼性などを検討していく必要があると考え る.

\section{本スケールの活用の実際と今後の展開}

本スケールを使用した研究について紹介する. 伊藤ら ${ }^{4}$ の研究では, グループホームに扔いて認知症高齢者を対 象にタッピング・タッチを行い, その効果について本ス ケールを用いて測定する研究であった. タッピング・ タッチとは, 指先の腹のところを使って, 軽く弾ませる

1 群馬県前橋市昭和町3-39-22 群馬大学大学院保健学研究科看護学講座

平成 25 年 9 月 6 日 受付

論文別刷請求先 $\overline{7} 371-8514$ 群馬県前橋市昭和町3-39-22 群馬大学大学院保健学研究科看護学講座 辻村弘美 
ように左右交互に優しくタッチすることを基本としたホ リスティックでシンプルなケアである. 介入 2 週間後で は,〈活動の楽しみ〉については変化が見られなかったも のの, 〈周囲との交流〉, 〈自分らしさの発揮〉, 〈満足・活気〉 の領域の平均值は上昇がみられ, タッピング・タッチの 効果があることが示唆された，その他，認知症の治療に おいては, 以前はドネペジル塩酸塩 (商品名アリセプト) が唯一の治療薬であったが, 2011 年には, メマンチン塩 酸塩 (商品名メマリー), ガランタミン臭化水素酸塩 (商 品名レミニール) などが国内でも使用されるようなり， 薬による症状の改善を評価するために, 本スケールを 使ってみたいとの相談を受けた，実際に，製薬会社の方 のお話を聞くと，笑顔が出ることを評価したいので，本 スケールを使ってみたいとのことであった，以上のよう に，ケアや投薬治療による効果を測定することや前述の おだやかに生活する認知症高齢者の生活背景などの特徵 を明らかにするために本スケールが活用できると考え る.

現在は, 在宅でも使用できる本スケールの開発に取り 組んでおり, 家族などの在宅での主介護者が評価し, 認 知症高齢者のその人らしさやおだやかさを大切にして介 護できるような研究をしていきたいと考える.

\section{最後に に}

本研究の一部を貴学会の学術雑誌に掲載してから, 教
育機関, 臨床現場, 製薬会社などから本スケールを使っ てみたいとの問い合わせがあった．また，本学大学院医 学系研究科長であった後藤文夫先生の著書 ${ }^{5} に も$ 本研究 の一部を紹介していただいた. このように,一つの論文 ではあるが，その揭載により世間に大きな影響を及ぼす ことを実感することができた。

今回, この流れを執筆することで, 自分自身の研究経 過や今後の課題などを再度振り返ることができた。この 場を与えていただいた北関東医学会編集委員会や事務局 の皆様にお礼申し上げたい.

\section{文献}

1. 2009 2012 年度 厚生労働省研究班調査 (代表者・朝田 隆 筑波大教授)

2. 辻村弘美, 小泉美佐子. 認知症高齢者の扔だやかスケール の開発. Kitakanto Med J 2010；60(2) : 119-134.

3. 小泉美佐子, 木村麗菜, 辻村弘美, 坂入和也. 認知症になっ てもおだやかに過ごす高齢者の特徵と背景 認知症のレ ベルと性格との関連についての予備的研究. 日本認知症 ケア学会誌 2008；7(2)：411.

4. 伊藤薰, 大西範和, 草川好子ら. 認知症グループホームに おけるタッピング・タッチ導入の試み〜おだやか尺度お よび認知症ケアマッピングを指標として〜. 日本認知症 ケア学会誌 $2011 ; 10(2): 323$.

5. 後藤文夫. 超高齢者医療の現場から「終の住処」診療記. 東京：中央公論新社, 2011：145-147. 